\title{
CULTURAL CONTROL OF CAMERARIA OHRIDELLA ON HORSECHESTNUT IN URBAN AREAS BY REMOVING FALLEN LEAVES IN AUTUMN
}

\author{
by Francesco Pavan, Paola Barro, Iris Bernardinelli, Nadia Gambon, and Pietro \\ Zandigiacomo
}

\begin{abstract}
Since the 1990s, the leafminer Cameraria ohridella has spread in central and southern Europe causing heavy damage on horsechestnut (Aesculus hippocastanum). Because biological control of the pest is not yet a reality, other measures must be adopted. Cultural control by removing fallen leaves of horsechestnut in autumn has often been proposed, and with this 3-year study the effectiveness of this practice under urban conditions has been shown and measured. The almost complete removal of leaves caused a significant reduction in infestation. The area of leaf surface injured decreased on average by more than $90 \%$ in early June, three quarters in late July, and a third in late August, and early leaf fall was always avoided. The proximity to sites with no leaf removal reduced the benefits of leaf removal as the season advanced. In the context of Integrated Pest Management, this cultural method contributes significantly to reduce $C$. ohridella damage.
\end{abstract}

Key Words. Cameraria ohridella; leafminer; Aesculus hippocastanum; damage; cultural control.

The horsechestnut leafminer, Cameraria ohridella Deschka and Dimic (Lepidoptera, Gracillariidae), was first observed in Macedonia in the 1980s and described as a new species in 1986 (Deschka and Dimic 1986). In the 1990s, heavy infestations on horsechestnut (Aesculus hippocastanum L.) were reported in several European countries (Tomiczek and Krehan 1998; Skuhravy 1999; Stigter et al. 2000). In north-eastern Italy, high population levels of this pest have been reported since the second part of the 1990s (Zandigiacomo et al. 1997; Hellrigl 1998; Pavan and Zandigiacomo 1999). The leafminer is now widespread in many areas of northern and central Italy (Gervasini 1999; Maini and Santi 1999; Parrini 1999).

The outbreaks of $C$. ohridella can cause early leaf fall, often followed by a second budding and refoliating in late summer. If these events are repeated every year, the survival of horsechestnut trees could be affected. Therefore, control measures must be adopted.

Biological control is to be hoped for, but the geographical origin and causes of $C$. ohridella outbreaks are still debatable (Holzschuh 1997; Kenis 1997). Moreover, in the countries where heavy infestations of the leafminer have been observed, no effective natural enemies have been found (Lethmayer and Grabenweger 1997; Pschorn-Walcher 1997; Grabenweger and Lethmayer 1999; Skuhravy 1999; Hellrigl and Ambrosi 2000).
Chemical control, either by aerial spraying (Blümel and Hausdorf 1996; Klara 1997; Krehan 1997a; Abraham et al. 1998) or tree injection (Feemers 1997; Krehan 1997b; Clabassi et al. 2000), has been proposed. Insecticide spraying is often difficult under urban conditions because of the height of trees and the small space around them. Environmental and health risks due to drift are additional problems.

Tree injection overcomes the above-mentioned drawbacks but are very expensive, and the holes drilled into the trunk year after year could injure trees.

Cultural control by removing fallen leaves, where the leafminer overwinters as a pupa, has also been suggested (Butin and Führer 1994; Klara 1997; Marx 1997; Tomiczek and Pfister 1997), but the effectiveness of this practice has not yet been assessed.

For this purpose, trials were carried out to test the effect of leaf removal in autumn on the population level of $C$. ohridella the following year.

\section{MATERIALS AND METHODS Locality and Years}

The research was carried out in Udine (northeastern Italy; $100 \mathrm{~m}$ altitude, $13^{\prime} 15^{\circ}$ longitude E, 46' $4^{\circ}$ latitude N) over three years (1998-2000). More than 600 horsechestnut trees are present in the urban and suburban areas.

\section{Comparison Between Sites with Different Levels of Cultural Control}

Sixteen sites with different numbers of horsechestnut trees were considered. Each site was characterized by a different level of fallen leaf removal in autumn (almost complete, partial, and scarce) and by proximity to other sites with a lower level of leaf removal (Table 1).

Fifteen sites were subdivided into three homogeneous groups:

1. "No removal" - scarce leaf removal (sites 1 through 5)

2. "Contiguous"-almost complete leaf removal, but adjacent to a "no removal" group (sites 6 through 10)

3. "Removal"-almost complete leaf removal and distant from a "no removal" group (sites 11 through 15).

Site 16 ("partial removal") was compared with two contiguous "removal" groups (sites 14 and 15). 
Table 1. Features of the different sites considered in Udine.

\begin{tabular}{lllll}
\hline & $\begin{array}{l}\text { Spatial } \\
\text { distribution } \\
\text { Site no. }\end{array}$ & $\begin{array}{l}\text { Level of } \\
\text { leaf removal }\end{array}$ & $\begin{array}{l}\text { Proximity to site } \\
\text { with a lower level of } \\
\text { fallen leaf removal }\end{array}$ & Group \\
\hline 1 & row & scarce & no & no removal \\
2 & row & scarce & no & no removal \\
3 & row & scarce & no & no removal \\
4 & row & scarce & no & no removal \\
5 & row & scarce & no & contiguous \\
6 & row & complete & contiguous to site 1 & contiguous \\
7 & row & complete & contiguous to site 2 & contiguous \\
8 & group & complete & 30 m from to site 3 & contiguous \\
9 & row & complete & in front of site 4 & removal \\
10 & row & complete & 30 m from site 5 & removal \\
11 & row & complete & no & removal \\
12 & group & complete & no & removal \\
13 & row & complete & no & removal \\
14 & circle & complete & $100 \mathrm{~m}$ from site 16 & \\
15 & row & complete & in front of site 16 & no \\
16 & row & partial & &
\end{tabular}

and (3) the average surface of large and small mines. In late August samples, the percentage of leaf surface injured was estimated by fixing a percentage equal to 0 and 100 for the leaves belonging to classes 0 and 6 , respectively, and a percentage equal to the mean of upper and lower limits for other classes.

An source of injury to horsechestnut leaves is the fungus Guignardia aesculi (Peck.) Stew. The surface occupied by the alterations due to this pathogen was not considered in the estimate of $C$. ohridella damage, except in the fallen leaves where the injury due to the fungus was also attributed to the leafminer. In such cases, we

\section{Samplings}

Each year, C. ohridella population density and/or leaf injury were estimated three times during the growing season (early June, late July, and late August). At each site, ten leaves of five trees were sampled. Before the first annual sampling, two shoots per plant were chosen at random in the lower part of the canopy and marked. Six basal leaves of one shoot and four leaves of the other were considered.

Each year in early June and late July, the number of mines per leaf was estimated by counting the rounded (small) and the irregular (large) mines present on each leaf. In late August, due to the impossibility of counting the mines in all the leaves, the infestation level was estimated using six classes of leaf surface injury: $0=0 \%, 1=1 \%$ to $10 \%, 2=11 \%$ to $25 \%, 3=26 \%$ to $50 \%, 4=5 \%$ to $75 \%, 5=$ $76 \%$ to $99 \%, 6=100 \%$ (fallen leaf).

During the first annual sampling, the length of the largest leaflet of each leaf was measured. During the last annual sampling in 1998, 200 leaves were collected and taken to the laboratory where the leaf surface was measured with a foliarimeter. The quadratic regressions between the length of the largest leaflet and the leaf surface was calculated $\left(y=0.10 x^{2}\right.$ $\left.+0.93 x-14.5 ; R^{2}=0.96\right)$. On the basis of this regression, the leaf surface of all sampled leaves was estimated.

During the second sampling in 1998, some leaves with mines were collected and taken to the laboratory where they were photocopied, then 100 small and 100 large mines were cut out and their total surface measured with a foliarimeter. The average surface of large and small mines was $1.80 \mathrm{~cm}^{2}$ and $0.32 \mathrm{~cm}^{2}$, respectively.

In early June and late July samples, the percentage of leaf surface injured was calculated on the basis of (1) the estimated leaf surface, (2) the number of small and large mines per leaf, speculated that without fungus attack, the insect would have injured the entire surface. The G. aesculi damage estimated in July 1998 and 2000 in each site was less than 5\% of leaf surface injured, except in site 5 in 1998 where it reached about 10\%. In 1999, the percentage of leaf surface injured by the pathogen, estimated using the six classes reported above, was higher than in the other two years: $20 \%$ on average in the "no removal" group, $9 \%$ in the "contiguous" group, and 3\% in the "removal" group.

\section{Statistical Analysis}

For statistical analysis, the ANOVA test was employed and the Tukey test was applied to compare groups. Before using ANOVA, the number of mines per leaf of each plant was transformed into square roots and the percentage of leaf surface injured into arcsines.

\section{RESULTS \\ Infestation Level}

In the "no removal" group, the percentage of leaf surface injured by C. ohridella ranged from 5\% in early June 1999 to 96\% in late August 2000 (Figure 1). The infestation level was lower in 1999 than in the other sampling years, but such difference was less at the end of August.

\section{Effect of Removal}

The "removal" group had a significantly reduced number of mines per leaf and percentage of leaf surface injured compared to the "no removal" group (Figure 2; Table 2). The difference in leaf surface injured between "removal" and "no removal" groups was on average 95\% in early June, $75 \%$ in late July, 30\% in late August and the early leaf fall was avoided. In 2000 no more differences were observed in late August. 
The "contiguous" group was similar to the "removal" group in early June and then gradually came to resemble the "no removal" group. In 1999, characterized by the lowest infestation level, the "removal" group was never significantly different from the "contiguous" group.

In late July, the "contiguous" and "no removal" groups differed only in the percentage leaf surface injured, except in 1999, because the former had a higher proportion of small mines on the total ones.

\section{Effect of "No Removal" Sites on "Contiguous" Sites}

In the "no removal" sites, the percentage of leaf surface injured in July was strongly correlated to that observed in June $(r=0.72 ; p<0.01)$. The same correlation was not observed in the sites of the "contiguous" group $(r=0.39$; NS). In that group, the percentage of leaf surface injured in July was significantly correlated to June infestations of the respective sites of the "contiguous" group $(\mathrm{r}=0.62 ; \mathrm{p}<$ 0.05 ), showing the migration of first-generation adults from the more infested site to the nearby less infested one.

\section{Effect of "Partial Removal" Sites on "Contiguous" Sites}

On the basis of the 3-year data, the "partial removal" site showed both more mines per leaf and a higher percentage of leaf surface injured than the two nearby sites of the "removal" group. The effect lasted up to late August, and it is significantly higher for the removal site more distant from the partial removal one.

The 1998 and 1999 data always agreed with the average of 3 years. In 2000, the percentage of leaf injured did not differ among the three sites in last sampling. In that year, the percentage of leaf surface injured observed in late July in the "partial removal" site was higher than in the other 2 years (14.1\% in 1998, 7.6\% in 1999, and 23.7\% in 2000) (Figure 3).

\section{DISCUSSION}

As expected, infestation in the "no removal" group rose dramatically during the season, reaching almost $100 \%$ of leaf surface injured by the end of August. The lower infestation observed at the beginning of summer 1999 could the result of the very high infestation recorded the previous year; many larvae could not complete their development because of a scarcity of food, and a lower number of pupae overwintered. On the other hand, the almost complete removal of fallen leaves in autumn effectively reduced the C. ohridella population density and leaf injury during the following year so that the injuries did not affect plant survival.

The proximity to sites with scarce leaf removal reduces the duration of the positive effect probably because adult leafminers migrate from the more infested sites to lesser ones. The higher the level of infestation during the first

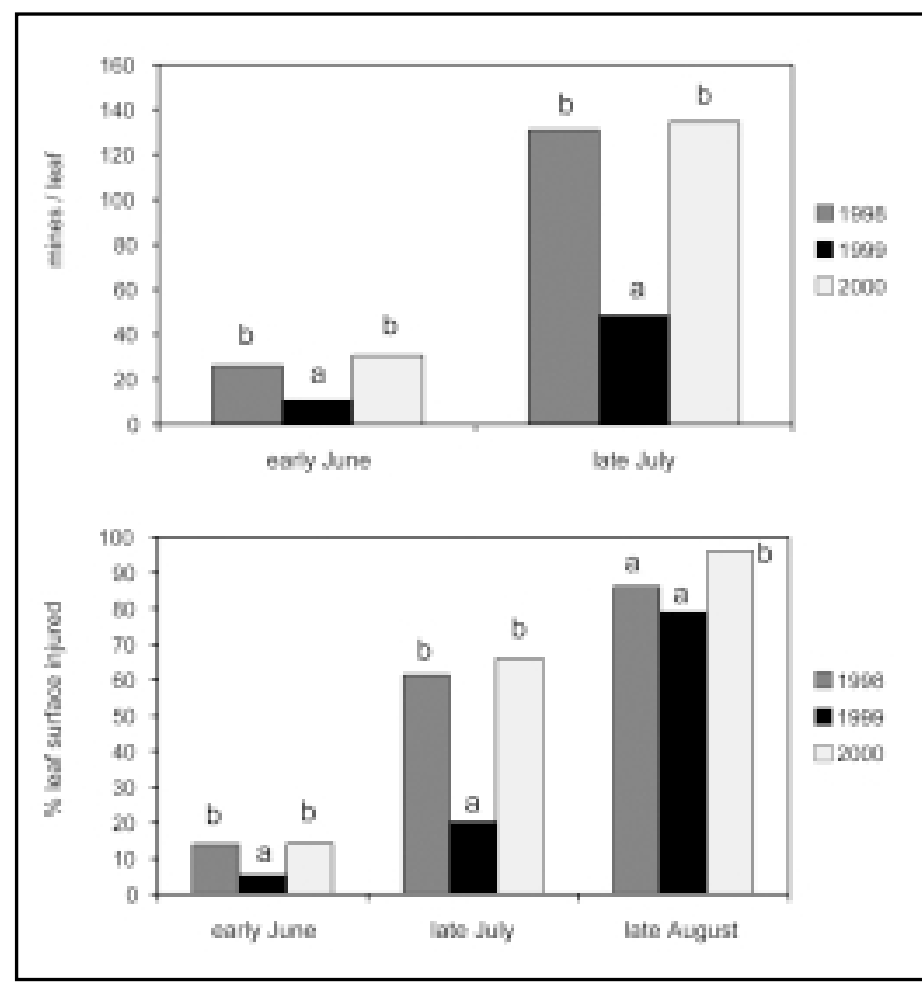

Figure 1. Infestation of C. ohridella observed during 1998, 1999, and 2000 in the sites of the "no removal" group. Inside each sampling period, bars with the same letter are not significantly different at the $\mathbf{0 . 0 5}$ level according to the Tukey test.

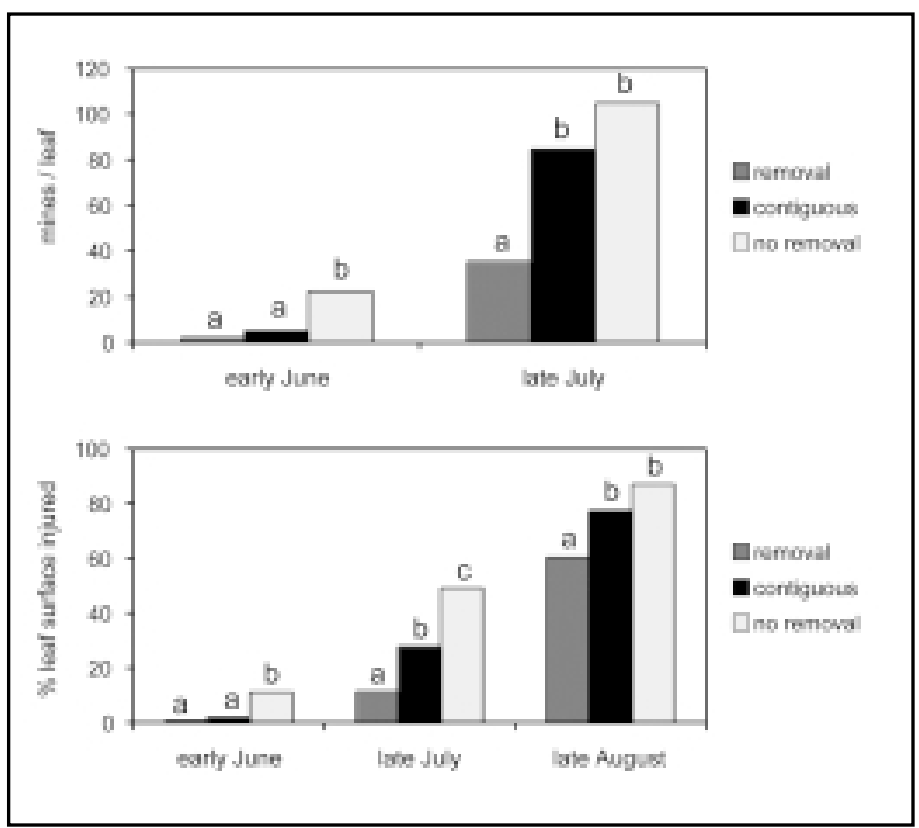

Figure 2. Average infestation (1998-2000) of C. ohridella observed during the vegetative season in the sites belonging to the three groups with different levels of fallen leaf removal. Inside each sampling period, bars with the same letter are not significantly different at the $\mathbf{0 . 0 5}$ level according to the Tukey test. 
generation (June) in the sites of the "no removal" group, the shorter was the benefit for sites of the "contiguous" group. In the case of proximity to a "partial removal" site, the positive effect of complete removal can last up to late August.

The effectiveness of cultural control as observed in this study is lower than that reported in literature for chemical control, but it is sufficient to prevent early leaf fall and a second refoliation. Moreover, cultural control does not pose environmental and health risks from insecticide spraying and, compared to tree injection, is less expensive.

In all urban conditions where complete leaf removal is easy, this control method must be encouraged. On the other hand, when the woody vegetation is impenetrable or in case of banks near horsechestnut trees, leaf removal could be too laborious.

Therefore, while waiting for a biological control method, cultural control in most cases appears sufficient to guarantee the survival of horsechestnuts, considering that cultural control also reduces G. aesculi damage (see, for example, 1999 data reported in Materials and Methods). In the context of Integrated Pest Management, most aesthetic injuries could be avoided if the trees were injected every 2 or 3 years. Moreover, the application in alternate years of chemical control and cultural control is useful to avoid the buildup of leafminer populations resistant to insecticide.

\section{LITERATURE CITED}

Abraham, G., B. Havasreti, and F. Lakatos. 1998. A vadgesztenyelevel-aknazomoly (Cameraria ohridella Deschka et Dimic 1986, Lepidoptera, Lithocolletidae) elterjedese es karsitasa gyormoson-sopron megyeben. Novenyvedelem. 34 (3):127-130 [in RAE]. the Tukey test.
Table 2. Average infestation of C. ohridella observed during 1998, 1999, and 2000 in the site ( 1 to 15) belonging to the three groups with different levels of fallen leaf removal.

\begin{tabular}{|c|c|c|c|c|c|c|}
\hline \multirow{2}{*}{$\begin{array}{l}\text { Year and } \\
\text { period }\end{array}$} & \multirow[b]{2}{*}{ Group } & \multicolumn{3}{|c|}{ Mines/leaf } & \multirow{2}{*}{$\begin{array}{l}\% \text { small } \\
\text { on total }\end{array}$} & \multirow{2}{*}{$\begin{array}{l}\% \text { leaf } \\
\text { surface injured }\end{array}$} \\
\hline & & Small & Large & Total & & \\
\hline \multicolumn{7}{|l|}{1998} \\
\hline \multirow{3}{*}{ Early June } & no removal & 6.5 & 20.2 & $26.7 b^{*}$ & 24 & $14.1 \mathrm{~b}$ \\
\hline & contiguous & 2.6 & 5.1 & $7.7 \mathrm{a}$ & 34 & $3.3 \mathrm{a}$ \\
\hline & removal & 0.5 & 1.5 & $2.1 \mathrm{a}$ & 25 & $1.0 \mathrm{a}$ \\
\hline \multirow[t]{3}{*}{ Late July } & no removal & 23.2 & 115.3 & $138.4 \mathrm{~b}$ & 17 & $61.4 c$ \\
\hline & contiguous & 47.8 & 82.8 & $130.6 \mathrm{~b}$ & 37 & $41.3 \mathrm{~b}$ \\
\hline & removal & 32.9 & 21.1 & $54.0 \mathrm{a}$ & 61 & $13.3 \mathrm{a}$ \\
\hline \multirow[t]{3}{*}{ Late August } & no removal & & & & & $86.1 \mathrm{~b}$ \\
\hline & contiguous & & & & & $87.7 \mathrm{~b}$ \\
\hline & removal & & & & & $56.3 \mathrm{a}$ \\
\hline \multicolumn{7}{|l|}{1999} \\
\hline \multirow[t]{3}{*}{ Early June } & no removal & 1.3 & 9.1 & $10.4 \mathrm{~b}$ & 12 & $5.3 \mathrm{~b}$ \\
\hline & contiguous & 0.2 & 1.8 & $2.0 \mathrm{a}$ & 10 & $0.7 \mathrm{a}$ \\
\hline & removal & 0.1 & 0.5 & $0.6 \mathrm{a}$ & 17 & $0.3 \mathrm{a}$ \\
\hline \multirow[t]{3}{*}{ Late July } & no removal & 12.1 & 37.2 & $49.2 \mathrm{~b}$ & 25 & $20.2 \mathrm{~b}$ \\
\hline & contiguous & 12.8 & 20.7 & $33.1 \mathrm{a}$ & 38 & $9.2 \mathrm{a}$ \\
\hline & removal & 8.7 & 7.9 & $16.6 \mathrm{a}$ & 52 & $4.8 \mathrm{a}$ \\
\hline \multirow{3}{*}{ Late August } & no removal & & & & & $79.0 \mathrm{~b}$ \\
\hline & contiguous & & & & & $51.2 \mathrm{a}$ \\
\hline & removal & & & & & $32.2 \mathrm{a}$ \\
\hline \multicolumn{7}{|l|}{2000} \\
\hline \multirow[t]{3}{*}{ Early June } & no removal & 6.7 & 24.0 & $30.6 \mathrm{~b}$ & 22 & $14.2 \mathrm{~b}$ \\
\hline & contiguous & 1.7 & 4.4 & $6.1 \mathrm{a}$ & 28 & $1.8 \mathrm{a}$ \\
\hline & removal & 1.0 & 1.5 & $2.6 \mathrm{a}$ & 40 & $0.8 \mathrm{a}$ \\
\hline \multirow[t]{3}{*}{ Late July } & no removal & 5.4 & 129.3 & $134.6 \mathrm{~b}$ & 4 & $66.1 \mathrm{~b}$ \\
\hline & contiguous & 14.1 & 75.5 & $89.7 \mathrm{~b}$ & 16 & $33.1 \mathrm{a}$ \\
\hline & removal & 2.9 & 31.5 & $34.5 \mathrm{a}$ & 8 & $16.2 \mathrm{a}$ \\
\hline \multirow[t]{3}{*}{ Late August } & no removal & & & & & $96.0 \mathrm{a}$ \\
\hline & contiguous & & & & & $92.3 \mathrm{a}$ \\
\hline & removal & & & & & $92.5 \mathrm{a}$ \\
\hline
\end{tabular}

*Inside each year and period, groups with the same letter are not significantly different at 0.05 level according to
Blümel, S., and H. Hausdorf. 1996. Erste Erfahrungen über die Bekämpfung der Roßkastanienminermotte. Österreichische Forstzeitung 107(5):39-41.

Butin, H., and E. Führer. 1994. Die Kastanien-Miniermotte (Cameraria ohridella Deschka \& Dimic), ein neuer Schädling an Aesculus hippocastanum. Nachrichtenbl. Deut. Pflanzenschutzd. 46 (5):89-91.

Clabassi, I., A. Tomè, G. Amaducci, and M. Lodi. 2000. Prove di lotta contro Cameraria ohridella Deschka et Dimic (Lep., Gracillaridae), dell' ippocastano con trattamenti endoterapici nella città di Trieste. Atti Giornate Fitopatologiche 1:419-426.

Deschka, G., and N. Dimic. 1986. Cameraria ohridella sp. n. (Lep., Lithocolletidae) aus Mazedonien, Jugoslawien. Acta entomologica Jugoslavica 22 (1-2):11-23. 
Feemers, M. 1997. Versuche zur Bekämpfung von Cameraria ohridella Deschka \& Dimic mittels Stamminjektion (Präparat: Confidor).

Forstschutz Aktuell 21:24-25.

Gervasini, E. 1999. Bilancio fitosanitario 1998. Informatore Fitopatologico 49 (1):24-26.

Grabenweger, G., and C. Lethmayer. 1999. Occurrence and phenology of parasitic Chalcidoidea on the horse chestnut leafminer, Cameraria ohridella Deschka \& Dimic (Lep., Gracillaridae). J. Appl. Entomol. 123(5):257-259.

Hellrigl, K. 1998. Verbreitung der makedonischen Roßkastanien-Minermotte Cameraria ohridella Deschka et Dimic, 1986 in Südtirol (Lepidoptera, Gracillariidae). Landesabteilung Forstwirtschaft der Autonomen Provinz Bozen-Südtirol, Schriftenreihe für wissenschaftliche Studien. 5:58 pp.

Hellrigl, K., and P. Ambrosi. 2000. Die Verbreitung der Roßkastanien-Minermotte Cameraria ohridella Deschka et Dimic (Lep., Gracillariidae) in der Region Südtirol-Trentino. Anz. Schadl. / J. Pest Sci. 73(2):25-32.

Holzschuh, C. 1997. Woher kommt die Roßkastanienminermotte wirklich? Forstschutz Aktuell. 21:11-12.

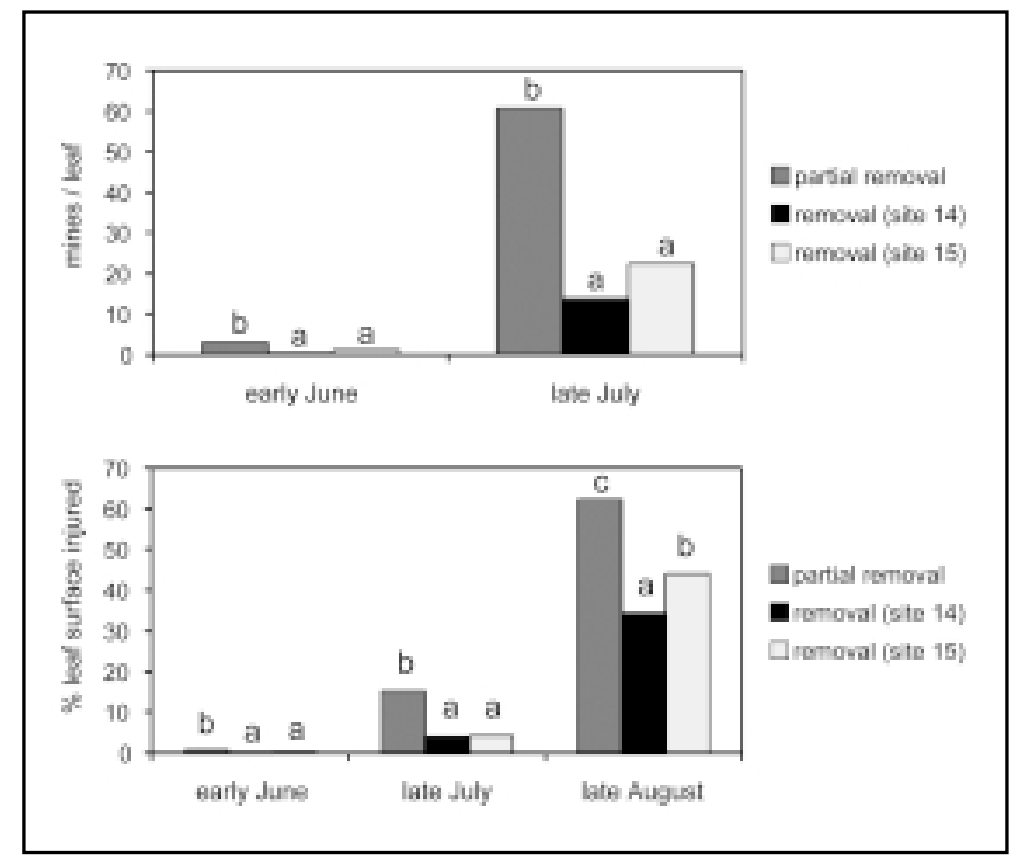

Figure 3. Average infestation (1998-2000) of C. ohridella observed during the vegetative season in the sites with different levels of fallen leaf removal. Inside each sampling period, bars with the same letter are not significantly different at the $\mathbf{0 . 0 5}$ level according to the Tukey test.

Kenis, M. 1997. Möglichkeiten einer biologischen Kontrolle von Cameraria ohridella mit eingeführten natürlichen Feinden. Forstschutz Aktuell. 21:27-29

Klara, K.N. 1997. A vadgesztenyelevel-aknazomoly (Cameraria ohridella Deschka et Dimic 1986) Kartetele a Fovaros kozteruletein. Novenyvedelem. 33(1):19-22 [in RAE].

Krehan, H. 1997a. Roßkastanienminermotte Cameraria ohridella-Vergleich der Bekampfungsverfharen. Forstschutz Aktuell. 19-20:2-7.

_ 1997b. Erste Erfahrungen mit Bauminfusionen gegen die Roßkastanienminermotte. Forstschutz Aktuell. 21:26

Lethmayer, C., and G. Grabenweger. 1997. Natürliche Parasitoide der Kastanienminermotte (Cameraria ohridella). Forstschutz Aktuell. 21:30.

Maini, S., and F. Santi. 1999. Cameraria ohridella microlepidottero dannoso all' ippocastano: prima segnalazione a Bologna e dintorni. Notiziario sulla Protezione delle Piante 10:73-77.

Marx, F. 1997. Maßnahmen gegen die Kastanienminermotte (Cameraria ohridella) aus der Praxis des Stadtgartenamtes der Gemeinde Wien. Forstschutz Aktuell. 21:21-22.

Parrini, C. 1999. Cameraria ohridella in Toscana. Notiziario Ce. Spe. Vi. 111:19-21.

Pavan, F, and P. Zandigiacomo 1998. Distribuzione di Cameraria ohridella in Italia ed entità delle infestazioni su ippocastano. Informatore Fitopatologico 48 (11):57-60.

Pschorn-Walcher, H. 1997. Zur Biologie und Populationsentwicklung der eingeschleppten Roßkastanien-Miniermotte, Cameraria ohridella. Forstschutz Aktuell. 21:7-10.

Skuhravy, V. 1999. Zusammefassende Betrachtung der Kenntnisse über die Roßkastanienminiermotte Cameraria ohridella Desch. \& Dem. (Lep., Gracillariidae). Anz. Schadl. / J. Pest Sci. 72:95-99.

Stigter, H., van Frankenhuyzen, A., and L.G. Moraal. 2000. De paardenkastanjemineetmot, Cameraria ohridella, een niewe bladmineerder voor Nederland (Lepidoptera: Gracillariidae). Entomologische Berichten. 8 (60):159163.

Tomiczek, C., and H. Krehan. 1998. The horsechesnut leafmining moth (Cameraria ohridella): A new pest in central Europe. J. Arboric. 24 (3):144-148.

Tomiczek, C., and A. Pfister. 1997. Bekämpfungsmöglichkeiten der Roßkastanienminiermotte. Österreichische Forstzeitung 108 (5):51-52.

Zandigiacomo, P., Pavan, F., Zangheri, S., Clabassi, I., and G. Stasi. 1997. Un minatore fogliare danneggia gravemente gli ippocastani in Friuli-Venezia Giulia. Notiziario ERSA. 10(5):14-17. 
Acknowledgments. We wish to thank Dr. L. Bernadis of Green Service of Udine town council for the organization of fallen leaf removal in different sites.

\author{
*Entomologists \\ Dipartimento di Biologia applicata alla Difesa delle Piante \\ Università di Udine \\ via delle Scienze, 208 \\ I-33100 Udine, Italy
}

* Corresponding author: Francesco Pavan.

Résume. Depuis les années '90, la mineuse des feuilles Cameraria ohridella s'est disséminée dans le Centre et le Sud de l'Europe, causant de lourds dommages sur le marronnier d'Inde (Aesculus hippocastanum). Comme le contrôle biologique de ce parasite n'est pas encore une réalité, d'autres mesures doivent être adoptées. Des mesures culturales de contrôle par le ramassage des feuilles de marronnier tombées au sol en automne ont souvent été proposées. Avec cette étude sur trois ans, l'efficacité de cette pratique en conditions urbaines a été démontrée et mesurée. Le ramassage quasi complet des feuilles a produit une réduction significative de l'infestation. La surface foliaire endommagée diminuait en moyenne de plus de 90\% au début de juin, du trois quart à la fin juillet et du tiers à la fin août, et enfin la chute prématurée des feuilles était toujours évitée. La proximité de sites où les feuilles n'étaient pas ramassées diminuait les bénéfices obtenus par le ramassage des feuilles au fur et à mesure que la saison avançait. Dans le contexte de la lutte intégrée contre les insectes et les maladies, cette méthode contribue à réduire significativement les dommages par C. ohridella.

Zusammenfassung. Seit den 90er Jahren verbreitet sich die Kastanienminiermotte in Zentral- und Südeuropa und verursacht schweren Schaden an Rosskastanien. Eine biologische Kontrolle ist nicht wirklich in Sicht, andere Methoden müssen verwendet werden. Es wurde oft vorgeschlagen, die Blätter von Rosskastanien im Herbst zu entfernen und mit dieser 3-jährigen Studie wurde die Effektivität dieser Praxis unter urbanen Bedingungen gezeigt und gemessen. Die nahezu komplette Entfernung der Blätter führte zu einer deutlichen Reduktion der Infestation. Die Fläche der kompletten verletzten Blattoberfläche reduzierte sich durchschnittlich um 90 \% im frühen Juni, 3/ 4 im späten Juli, 1/3 im späten August. Früher Blattfall wurde immer verhindert. Die Nähe zu Standorten ohne Laubentfernung reduzierte mit fortschreitender Jahreszeit die Vorteile der Laubentfernung. Im Zusammenhang mit Integriertem Pflanzenschutz trug diese Methode signifikant dazu bei, C. ohridella-Schaden zu reduzieren.
Resumen. Desde 1990 el minador de la hoja Cameraria ohridella se ha propagado en Europa central y meridional causando graves daños en el castaño (Aesculus hippocastanum). Debido a que el control biológico de la plaga aún no es una realidad, se han adoptado otras medidas. El control cultural por remoción de las hojas en el otoño se ha propuesto con frecuencia; y con este estudio de tres años bajo condiciones urbanas ha sido demostrada y medida la efectividad de esta práctica. La remoción casi completa de las hojas causó una reducción significante en la infestación. El área foliar dañada disminuyó en promedio más del $90 \%$ a comienzos de Junio, tres cuartas partes a finales de Julio, y una tercera a fines de Agosto. Además, se evitó siempre la caída prematura de otoño. La proximidad a los sitios con hojas no removidas redujo los beneficios de la remoción del follaje a medida que avanzaba la estación. En el contexto de un Manejo Integrado de Plagas este método cultural contribuye significativamente a reducir el daño de C. ohridella. 